\title{
Impact of Accounting Software among SMEs Accountants in Oman
}

\author{
http://doi.org/10.21272/fmir.4(2).25-33.2020
}

Mohammed Muneerali Thottoli, ORCID: https://orcid.org/0000-0003-2195-7226

University of Nizwa, College of Economics, Management \& Information Systems, Oman

\begin{abstract}
Financial losses, bankruptcy and closure of the company may be the result of incorrect choice of accounting software, inefficient modernization of such software depending on the specifics of the economic entity and ignorance of technical knowledge of staffs to work with the software product. The paper notes that for companies from member countries of the Gulf Cooperation Council, the technique of implementation and application of tax legislation and International Financial Reporting Standards (IFRS) differs significantly from other countries. The article emphasizes that in Oman, companies need to prepare financial statements in accordance with current applicable IFRS, as well as the Law on Commercial Companies 2019 and the guidelines and requirements for disclosure of capital market information. The purpose of this paper is to study and study the impact of the implementation of accounting software among small and medium enterprises (SMEs) in Oman. The study systematizes the features and issues of assessing the relationship between generalized accounting software (GAS) and its use by accountants working for SMEs. Twenty small and medium business accountants were selected as the target audience, taking into account their experience and basic knowledge of accounting in the context of ownership and use of GAS. The study confirms and theoretically proves that the use of GAS in the financial and economic activities of SMEs has a significant impact on the practice of accountants working in such enterprises, ie, there is a positive and significant relationship between GAS choice and use of GAS by SME accountants. The results of this study can be useful for the government, representatives of tax authorities, higher education institutions in the context of establishing adequate policies regarding the use of software for accounting by economic entities.
\end{abstract}

Keywords: Generalized accounting software, accounting, accountant, small and medium enterprises, international financial reporting standards (IFRS), Oman

JEL Classification: M41, L86, M15.

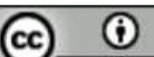

Cite as: Muneerali M. T. (2020). Impact of Accounting Software among SMEs Accountants in Oman. Financial Markets, Institutions and Risks, 4(2), 25-33. http://doi.org/10.21272/fmir.4(2).25-33.2020.

(C) The Author, 2020. This article is published with open access at Sumy State University.

\section{Introduction}

Today, accounting department plays an important role in any business sectors especially in SMEs. Accounting plays a crucial role in the operations of SME sectors. Since SMEs has numerous debtors (accounts receivables) and creditors (accounts payable), it increases the importance of keeping books of accounts on accrual basis. Recently, the use of Information Technology (IT) in accounting is extensively used and has turned into a daily practice. Therefore, it is very hard to perform most of the accounting entries, financial operations and financial statements without the using IT (Damasiotis, Trivellas, Santouridis, Nikolopoulos, \& Tsifora, 2015). The ageing of the debtors needs to be kept up to date for the success of the organization. SMEs increasingly need accounting software technologies for the sustainability of their business' growth (Putra, 2019). IT and accounting software have reduced the time needed by accountants to prepare and present financial statements to management (Teru, Idoko, \& Bello, 2019; Ghasemi, Shafeiepour, Aslani, \& Barvayeh, 2011). Accounting software provides companies to generate various reports quickly and easily for decision making by management (Thottoli, Thomas \& Ahmed, 2019a; Janvrin, \& Watson, 2017; Aduamoah 2017). Computerized accounting systems increases accuracy, overall functionality, quick processing and generation of fair financial statements and other reporting (Tilahun, 2019; Mauch, Cannam, Bittner, Fazekas, Salamon, Dai \& Dixon, 2015). Information Communication Technology (ICT) is a main basis of cost-effective along with competitive advantages for SMEs to compete with their competitors and to reach customers globally (Udegbunam, Uchenu, 
Odimmega, \& Nwogu, 2017). Accounting assumes a major role in the success or failure of recent firms or organization (Amanamah, Morrison, \& Asiedu, 2016). Computerized accounting system were intended to help in the management to control firms' economic-financial area (Horvat, \& Mojzer, 2019; Shiraj, 2015). The computerized accounting provides better internal control report system for any given period of time (Arcega, Datinguinoo, Guerra, Guno, Mayuga, Villamena, \& Manongsong, 2015). Computerized accounting helps to track customers and suppliers of a business (Amanamah et al., 2016).

Research findings have also showed some major problems faced by SMEs are incomplete records, lack in control of finance, staff inexperience, poor power supply, and such others (Ogundana, Okere, Ayomoto, Adesanmi, Ibidunni \& Ogunleye, 2017). Wrong selection of accounting software for a company may leads to financial losses, bankruptcies of the company, closure of the company and losses of jobs to accounting personnel (Aduamoah, 2017). The adoption of computerized accounting system leads to accountants who can use specific software and thus costs more (Taiwo, 2016). Since computerized accounting is working under information system, the accountant needs to explain what they need (Gordon, 2018). A good computerized accounting system can cost thousands and even millions of dollars, depending on the complexity and the size of the organization (Amahalu, Abiahu, \& Chinyere, 2017; Arcega et al., 2015). The problems associated with the implementation of Computerized Accounting Information System (CAIS) such as high costs of implementations of hardware and software (Brandas, Megan, \& Didraga, 2015). Computerized accounting system affects costs of implementation and it require special skilled employees (Lee, \& France, 2018). Other challenges while using computerized accounting are reduction of accountants, inadequate security and having quality of backup and print accessories (Isa, 2017). Frequent power failure is a biggest problem (Amanamah et al., 2016). IT infrastructure here also includes IT experts that can design, install, fix and maintain the systems and special IT personnel to maximise the usage of such technologies and systems and even train others (Turner \& Weickgenannt, 2020; Taiwo, 2016). Staff and workers of computerized environment have to be trained and qualified in order to make efficient use of the new technologies (Do, Tran, Nguyen, Truong, \& Pham, 2018). The accountant's adaptability of software accounting entirely by organization is a question and management may not willing to change from manual to cent percentage computerized environment (Heredos, Kim, \& Vazzano, 2017). There is no much specific study done in Oman relating to the impact of accounting software in SMEs accountants. Hence the current study intends to fill the gap in the research literature by evaluating the impact of accounting software among SMEs accountants in Oman. Thus, this study is aimed to examine the impact of Accounting Software among Small and Medium Enterprises (SMEs) Accountants in Oman.

\section{Literature Review}

There are number of literature appropriate to the current studies were identified. For instance, according to Valerie, Abolade and Rowland, (2019); Tijani and Mohammed, (2013), majority SMEs are not acquiescent with e-commerce. Accounting software were shared with SMEs were general accounting systems, specialpurpose systems, and office automation systems. Most of them were Vendor-Supported Systems. Kanakriyah, (2016); Haleem, and Raisal, (2016), evaluated the impact of adoption of computerized accounting information systems on the basis of its quality, measure and assess the economic feasibility of using such system, and to know the difficulties come upon the adoption and use of computerized accounting information systems. Boylan, and Dennery, (2018); Zimmerman, and Libby, (2017), suggests that small business owners should invest in Accounting Information System (AIS) to complete quick and fast bookkeeping \& payroll tasks. Turner and Weickgenannt, (2020), were opined that computerized accounting helps SMEs easy use of software and requires minimal training to the accountants. Putra, Y. M. (2019), argue that accounting software technology is affordable for the business owners to adopt. This cost is comparatively lesser when compared to outsourcing accounting services. Sallem, Nasir, Nori, and Kassim, (2017) suggest that using computerized accounting by SMEs may avoid outsourcing of accounting work. Ahmad, and Al-Shbiel, (2019), Zotorvie, (2017), SMEs should use computerized accounting in order to complete bookkeeping and payroll tasks by themselves to prepare fair financial statements and file income tax return on timely basis. Valerie et al., (2019); Putra, (2019), found that higher-level of analysis using accounting software helps to control customers and thereby increasing sales. Udegbunam et al., (2017), Accounting software helps to increase efficiency of accountants and helps them to meet stakeholders' requirements including tax services. Aduamoah, (2017), stated that SMEs should increase cyber security and data protection while using computerized accounting systems in their business. Alabdullah, Ahmed and Muneerali, (2019); Chong and Nizam, (2017), suggested that accounting software helps organization by improved data process speed, reliable and accurate data entry 
with good corporate governance were can be ensured. According to, Thottoli, Thomas, and Ahmed, (2019b); Thottoli et al., (2019a); Rosli, Yeow, and Siew, (2012), many of audit firms' clients were using adopt and use accounting software to record daily transactions in order to process and disseminate accounting information to its stake holders including management. Thottoli, Thomas and Ahmed, (2019c), were found that accounting and auditing firms were used IT software using for making easy for auditing and accounting task. Amahalu et al., (2017), recommends that micro finance banks should adopt IT accounting system instead of doing accounting manually. Because it may positively affect banks profitability level. Azih, N. (2018); Ogundana et al., (2017), findings revealed that timely management information, recording of large accounting transactions, reduction of manual and clerical work and better stakeholder satisfaction. Putra, Y. M. (2019), found that SMEs who keeps proper books of account using IT software are often capable of attracting external financing than those with incomplete records keeping manually. Warren Jr, J. D., Moffitt, K. C., \& Byrnes, P. (2015), wish to express that usage of accounting software by SMEs has the potential to improve their performance in financial reporting of activities in the organization. Agburu, Anza, and Iyortsuun, (2017), found that outsourcing of accounting works by SMEs are common. Thottoli, Thomas and Ahmed, (2019a); Seethamraju, R. (2015), were opined that financial affordability of SMEs decides adoption of accounting software. The level of information required also matter for the adoption of accounting software. Putra, Y. M. (2019), in findings states that there is significant influence on use of computerized accounting software which relates to factors such as business size and external environment. Ngoo, Tiong, and Pok, (2015), in their opinion it has argued that extensive theoretical and practical knowledge of various accounting software should include in the curriculum of graduate studies.

\section{Methodology}

The study has examined the impact of generalized accounting software among SMEs accountants. For the purpose of this study the type of research design to be used a purposive sampling technique to select the required respondents for the survey (Teddlie \& Tashakkori, 2009). The sampling technique has used in this study by selecting accountants from various SMEs in Oman. The total number of sample size for the survey is twenty (20) SMEs accountants, which are carefully chosen as the target respondents. The basis for chosen the respondents is because of their current practices in the field of accounting, use of generalized accounting software and Ms Excel in their practical applications within selected SMEs. Through this medium, this study has provided a justifiable practical accounting experience with the respondents to increase the quality and validity of the questions and accordingly the examination, analysis, and to allow questions that supplement the study with clarifications where needed. Respondents were able to describe their views much in detail and were discussed several issues which may be sensitive on a personal and confidential basis. The objective of using the interview method in this study is to examine whether generalized accounting software impact on SMEs accountants.

\section{Discussion}

4.1 The Impact of Accounting Software on SMEs Accountants. There are various recent studies in the field of accounting software (e.g., Putra, 2019; Tilahun, 2019; Mauch, Cannam, Bittner, Fazekas, Salamon, Dai \& Dixon, 2015; Thottoli, Thomas \& Ahmed, 2019a) have been done to strengthen current study and its results of the approach analysis. In the $2^{\text {nd }}$ stage of interview, the respondents were asked to comment on current accounting software (such as Oracle, Orion, SAP, Tally, Al Shifa Programs, Quick Books, Controman, Sparc, Reckoner system, DFM, ERP, Mawred Alnizam Al mali) which they use. Majority of the software they use generalized accounting software that can be readily available in the software market. Further, we asked about various barriers facing while using that software. Pre-training is an essential element before implementing computerized accounting system in SMEs. This has been supported by one interviewee (P1) opined that [...] "new employees are not trained on using software program is a barrier". Rahman, Ahammed, Uddin, Rouf and Uddin, (2015) in their study were supported that training is a major factor of barrier that will affect fair recording of transactions using accounting software among SMEs accountants of Bangladesh. Some of the generalized accounting software needs to update frequently in order to function quickly, this has supported by an interview with (P2) and opined that [...] "inability to run reports quickly is a barrier". Some of the generalized accounting software are slow. This has supported by an interviewee (P3) was opined that [...] "speed in closing the computer before the work save is a barrier" and Another interviewee (P12) supported P3 and opined that [...] "fast shutdown device in recoding is a barrier". Houaich and Belaissaoui, (2015) argued that shutdown of the electronic payment system may affect adversely on the turnover of the SMEs. Internet access, availability and speed is different in different location. This has been agreed by an interview 
with (P4) and has been opined that [...] "slow Internet is a barrier". Afolayan, Plant, White, Jones and BeynonDavies, (2015) found that lack in access of internet and low speed may adversely affect to the adoption of IT in Nigerian SMEs. Majority of accounting works are using computer and keeping those reports only in system. SMEs may not buy and update licensed version of antivirus. This may lead to virus attack by computer system and end up with loss of important information. This has been supported by with an interviewee (P5) and opined that [...] "frequent viruses in computer is a barrier"; (P6) opined that [...] "safety and security is a barrier" and another interviewee with (P11) also opined that [...] "virus attack is a barrier". This has been supported by NGUGI, (2016) where they suggested that countermeasures need to be taken such as antivirus and such other firewalls were seen to be the most preferred countermeasures among SMEs. Some of newly recruited accounting staffs has less knowledge about accounting principles and concepts. This has been agreed by an interview done with (P7) and opined that [...] "lack of accounting knowledge is a barrier". Some of the freshly graduated accounting major candidates don't have enough practical experience. Since SMEs are appointing fresh graduates for dealing accounting functions will face prone to make errors when entering transactions through computerized software. This has evidently agreed by an interview with (P8) and opined that [...] "lack of experience is a barrier"; another interviewee (P9) opined that [...] "not all employees have knowledge or experience in using this accounting software is a barrier" and interviewee (P10) opined that [...] "lack of concentration \& knowledge in the basics of accounts is a barrier". This is in consistent with the study of Putra, (2019); Nyathi, Nyoni, Nyoni and Bonga, (2018) which found that the lack of knowledge in GAAP, lack of knowledge in accounting software, non-availability of experienced people and lack of practical skills in accounting software to do accounting functions are major challenges facing by SMEs. Computer system requires strong protection with password. Since responsible accountant takes un informed leave may lead delay in updating current transactions in the system. This challenge has been reiterated by an interview has done with (P13) and opined that [...] "use more than one user password cause a serious challenge"; Anokyewaa, (2016) expressed a major limitation on the part of SMEs about the inability to record daily transactions in the computerized accounting system leads to adverse effect on their operations. Some of the SMEs accountants may not have the knowledge of current Generally Accepted Accounting Principles (GGAP), applicable International Financial Reporting Standards (IFRS) and Oman Commercial company laws. This has supported by an interview conducted with (P14) were he has opined that [... "failure to standardize accounting rules in institutions is a barrier". Sithole, (2015) states that SMEs accountant lack in knowledge of the current accounting standard or GAAP which should require for financial reporting. Some of the accounting staffs are lazy in their work. They were recruited as per legal requirements as part of Omanisation. This may lead to lack of seriousness in their assigned tasks. This has been supported with an interview conducted with (P15) and opined that [...] "more time used social system from work and sometime used Excel account is a barrier". Accountants may enter duplicate transaction entry because of confusion. Ngaochay, and Walsh, (2017) noted that employees sometime may lazy, dislike their duties and responsibility. Some of the generalized accounting software may not have facility to examine duplicate transactions. This has supported by an interview conducted with (P16) and opined that [...] "confusion is a barrier" Pudiyaveetil, Nayani and Varghese, (2016) has supported the comments as some of the accounting software may not have examining or auditing facilities. Further, we asked about errors facing while using computerized accounting software. Some errors are not affecting trail balance. Hence it is difficult to find out the route cause. Some of the generalized accounting software may not suitable for a specific type of company. This has been supported by conducting an interview with (P17) and opined that [...] "lack of efficiency in the software" Bishop, (2016) argued that smaller version of accounting software packages may contribute inefficiency in its functions. Accountants who don't have thorough knowledge about basic principle may occur errors of principles. This has been supported by one interviewee (P19) and opined that [...] "entry record in wrong account" and another interviewee (P20) opined that [...] "forget about recording small transactions" Pavtar, (2017) in his study try to expose that error of principle, errors of omission, errors of transposition and incomplete entries are common in SMEs. Generally, the findings of the semi-structured interviews have validated and consistent with this qualitative research. Finally, the research has supported the factors such as barriers and errors (of accounting software) had significant impact among SMEs accountants.

\section{Conclusion}

Majority of the SMEs not able to afford customized accounting software, may go for generalized accounting software or even continue manual accounting. Since IT has globalized, SMEs needs to adopt IT to better perform their functional activities. SMEs simply select generalized accounting software that may not provide 
functionalities the SMEs required to manage their operational process. A plenty of available literature was revived to know various barriers and errors to identify the accountant's requirements, barriers and errors commonly seen with SMEs accountants. For each of these accountants' requirements, barriers and errors in SMEs accountants, accounting software functionalities and accountants' skills and knowledge were analyzed that will be required in order for SMEs accountants to provide specific information. The findings provided evidence that the GAS have a significant impact on practice of SME accountants, meaning that there is a positive and significant relationship between the selection of GAS and the usage of such GAS by SMEs Accountants. As part of this study we were selected SMEs accountants requirements identified by literature study included training, system efficiency, internet availability and its speed, virus threat and security, knowledge and skills of accounting and accounting software, experience level, approach of accounting staffs in their assigned tasks, practical and theoretical knowledge, knowledge about GAAP and accounting principles, errors of principle, errors of omission, errors of commission, errors of transposition, errors in duplicate entry and cost of the software. It is important to invest time for taking correct decision for recruiting suitable accounting staffs, their accounting skills and knowledge both in theory as well as practical and selection of suitable accounting software package which is most suitable for concerned SMEs. Not all generic accounting software are suitable for all SMEs, they may need to go for customized accounting software in order to provide best accounting functionalities. This leads management to take strategic planning for their sustainable profitability by adopting best computerized accounting practices in an organization. Further, higher educational institutions through various colleges and universities in Oman should bring a policy to include and ensure that the graduating students has sufficiently acquaint enough practical accounting software through industrial training.

\section{Implications}

The current study has several implications. Management and accountants of SMEs required to produce various financial and non-financial reports as and when required by any stakeholder using accounting information. First and foremost, implication of this study is to enrich SMEs accountants and ensure that their tasks are efficiently and effectively carried on. This study would be useful to identify various barriers and errors happening while adopting and using computerized accounting software. The study also helps to take decision by SMEs management and accountants on selection of best accounting software. They have to decide whether generalized accounting software or specific accounting software is suitable for the company. SMEs management should be given importance when recruiting accounting staffs. The adoption of generalized or customized accounting software by SMEs will enhance efficiency and effectiveness of accounting staffs and thereby ensuring fairness while preparing financial statements. Thus, this study helps to identify various possible barriers and errors of SMEs accountants. This study also helps to assist policy makers of the country, tax authorities and higher educational institutions through colleges and universities in particular, to set adequate policies related to accounting software.

\section{Limitations and Future Research}

For the study it has considered a limited variable that have taken to study SMEs accountants. There could be many other factors involved to the impact of accounting software to enhance efficiency of SMEs accountants that can be investigate and examine in future studies. Further, the study is limited to the qualitative analysis and recommended to apply quantitative analysis for future researchers especially on each of the independent variable in order to expose various challenges facing by SMEs accountants. Further, this study limited samples selected from SMEs in Oman.

\section{References}

1. Aduamoah, M. (2017). Riding the waves of technology: A study into how SMEs select computerized accounting software (CAS) supplier in developing countries. Archives of Business Research, 5(10), DOI: https://doi.org/10.14738/abr.510.3652

2. Afolayan, A., Plant, E., White, G. R., Jones, P., \& Beynon-Davies, P. (2015). Information technology usage in SMEs in a developing economy. Strategic Change, 24(5), 483-498, DOI 10.1002/jsc.2023.

3. Agburu, J. I., Anza, N. C., \& Iyortsuun, A. S. (2017). Effect of outsourcing strategies on the performance of small and medium scale enterprises (SMEs). Journal of Global Entrepreneurship Research, 7(1), 26, DOI: https://doi.org/10.1186/s40497-017-0084-0.

4. Ahmad, M. A., \& Al-Shbiel, S. O. (2019). The Effect of Accounting Information System on Organizational Performance in Jordanian Industrial SMEs: The Mediating Role of Knowledge 
Management. International Journal of Business and Social Science, 10(3). https://www.ijbss.org/journals/Vol_10_No_3_March_2019/9.pdf. Accessed 18 May 2020.

5. Alabdullah, T. T. Y., Ahmed, E. R., \& Muneerali, M. (2019). Effect of Board Size and Duality on Corporate Social Responsibility: What has Improved in Corporate Governance in Asia?. Journal of Accounting Science, 3(2), 121-135, DOI: https://doi.org/10.21070/jas.v3i2.2810

6. Amahalu, N., Abiahu, M. F. C., \& Chinyere, O. (2017). Comparative analysis of computerized accounting system and manual accounting system of quoted Microfinance Banks (MFBs) in Nigeria. International Journal of Academic Research in Accounting, Finance and Management Sciences, 7(2), 30-43, DOI: $10.6007 / \mathrm{IJARAFMS} / \mathrm{v} 7-\mathrm{i} 2 / 2787$.

7. Anokyewaa, C. (2016). Computerized record keeping among small and medium enterprises-a case study in Sunyani Municipalit, PhD diss., 2016. Resource document. http://dspace.knust.edu.gh/bitstream/ 123456789/8497/1/ANOKYEWAA\%20CHRISTIANA.pdf. Accessed 12 May 2020.

8. Arcega, C. K., Datinguinoo, E., Guerra, J., Guno, C., Mayuga, H. J., Villamena, E., \& Manongsong, J. L. (2015). Computerized vs. non-computerized accounting system of small and medium enterprises in Lipa City, Philippines: A comparative analysis. Asia Pacific Journal of Academic Research in Business Administration, 1(1). http://research.lpubatangas.edu.ph/wp-content/uploads/2015/05/APJARBA-20151-006-Computerized-vs.-Non-computerized-Accounting-System.pdf. Accessed 18 May 2020.

9. Azih, N. (2018). Electronic accounting: An imperative tool for quality assurance in accounting education programme in the digital era. Nigerian Journal of Business Education (NIGJBED), 1(2), 90-98. http://www.nigjbed.com.ng/index.php/nigjbed/article/view/161. Accessed 18 May 2020.

10. Brandas, C., Megan, O., \& Didraga, O. (2015). Global perspectives on accounting information systems: mobile and cloud approach. Procedia Economics and Finance, 20, 88-93, DOI: 10.1016/S22125671(15)00051-9.

11. Bishop, W. A. (2016). Addressing the challenge of strategic alignment faced by small and medium-sized entities during the selection of accounting software packages, DOI: 10.19030/iber.v16i1.9883.

12. Boylan, D. H., \& Dennery, C. (2018). Accounting Software and Its Effect on the Demand for Accountants in Small Business, Accountancy Business and the Public Interest 2018. Resource document. http://visar.csustan.edu/aaba/BoylandBoylandDennery2018.pdf. Accessed 12 May 2020.

13. Damasiotis, V., Trivellas, P., Santouridis, I., Nikolopoulos, S., \& Tsifora, E. (2015). IT competences for professional accountants. A review. Procedia-Social and Behavioral Sciences, 175, 537-545, DOI https://doi.org/10.1016/j.sbspro.2015.01.1234.

14. Do, D., Tran, M., Nguyen, T., Truong, D., \& Pham, D. (2018). Determinants influencing differences of financial statements under Vietnamese accounting and international accounting: The case of Vietnam. Management Science Letters, 8(6), 555-568, DOI: 10.5267/j.msl.2018.4.034.

15. Fordham, D. R., \& Hamilton, C. W. (2019). Accounting Information Technology in Small Businesses: An Inquiry. Journal of Information Systems, 33(2), 63-75. DOI: https://doi.org/10.2308/isys-51982.

16. Ghasemi, M., Shafeiepour, V., Aslani, M., \& Barvayeh, E. (2011). The impact of Information Technology (IT) on modern accounting systems. Procedia-Social and Behavioral Sciences, 28, 112-116, DOI:10.1016/j.sbspro.2011.11.023.

17. Gyimah, P., Appiah, K. O., \& Lussier, R. N. (2019). Success versus failure prediction model for small businesses in Ghana. Journal of African Business, 1-20. DOI https://doi.org/10.1080/15228916.2019.1625017. Accessed 19 May 2020.

18. Haleem, A., \& Raisal, I. (2016). The study of the influence of information technology sophistication on the quality of accounting information system in bank branches at Amapara district, Sri Lanka. http://ir.lib.seu.ac.lk/handle/123456789/1944. Accessed 18 May 2020.

19. Heredos, S., Kim, P., \& Vazzano, B. (2017). LOOKS DO MATTER: DEVELOPING AN ACCOUNTING SOFTWARE PROGRAM IN JAVA AND NETBEANS. Issues in Information Systems, 18(3). https://iacis.org/iis/2017/3_iis_2017_9-18.pdf. Accessed 18 May 2020.

20. Horvat, T., \& Mojzer, J. (2019). Influence of Company Size on Accounting Information for DecisionMaking of Management. Naše gospodarstvo/Our economy, 65(2), 11-20, DOI:https://doi.org/10.2478/ngoe-2019-0007.

21. Houaich ${ }^{1}$, Y. A., \& Belaissaoui, M. (2015). Towards a New Evaluation Model to Improve Open Source Software-Application in Moroccan SMEs. International Journal of Computer Science and Mobile Computing (IJCSMC), 4(7), 364-374. https://www.researchgate.net/profile/ Youssef_Ait_Houaich 
/publication/302494662 Towards a New Evaluation Model to Improve Open Source Software Ap plication in Moroccan_SMEs/links/5730ad3408aed286ca0db9ae.pdf. Accessed 18 May 2020.

22. Janvrin, D. J., \& Watson, M. W. (2017). "Big Data": A new twist to accounting. Journal of Accounting Education, 38, 3-8, DOI: 10.1016/j.jaccedu.2016.12.009.

23. Kanakriyah, R. (2016). The Effect of Using Accounting Information Systems on the Quality of Accounting Information According to Users Perspective in Jordan. Journal of Accounting, Auditing and Finance Research, 4(11), https://www.researchgate.net/profile/Raed_Kanakriyah/publication/335665572_Published_by_European Centre_for_Research_Training_and_Development_UK_wwweajournalsorg/links/5d72cf78a6fdcc9961 b2d5cf/Published-by-European-Centre-for-Research-Training-and-Development-UKwwweajournalsorg.pdf. Accessed 12 May 2020.

24. Kucherenko, V. A., \& Mirontseva, S. S. (2017). Differences Between Manual and Computerized Accounting System. In Recent Achievements and Prospects of Innovations and Technologies (pp.255257). https://www.elibrary.ru/item.asp?id=29268887. Accessed 19 May 2020.

25. Lee, H., \& France, A. (2018). Contrasting the accounting difficulties of small to medium entities (SMEs) with large organisations, Resource Document. http://researcharchive.wintec.ac.nz/ 6490/2/ AMCVol1\%20no2\%20excl\%20conf.pdf. Accessed 12 May 2020.

26. Mauch, M., Cannam, C., Bittner, R., Fazekas, G., Salamon, J., Dai, J., ... \& Dixon, S. (2015). Computeraided melody note transcription using the Tony software: Accuracy and efficiency. https://zenodo.org/record/923767\#.XsKLYmgzbIU. Accessed 18 May 2020.

27. Ngaochay, T., \& Walsh, J. (2017). Upgrading Employees Skills in Thai SMEs Sustainably. PACIFIC BUSINESS REVIEW INTERNATIONAL, 9(9), http://www.pbr.co.in/2017/2017_month/March/15.pdf. Accessed 18 May 2020.

28. Ngoo, Y. T., Tiong, K. M., \& Pok, W. F. (2015). Bridging the gap of perceived skills between employers and accounting graduates in Malaysia. American Journal of Economics, 5(2), 98-104. DOI:10.5923/c.economics.201501.09.

29. Ngugi, E. W. (2016). E-Commerce Security and Performance of SMEs in Nairobi, Kenya (Doctoral dissertation, University of Nairobi). Resource Document. https://pdfs.semanticscholar .org/0304/3ad525928b4affae00ed4046242183df034c.pdf. Accessed 12 May 2020.

30. Nyathi, K. A., Nyoni, T., Nyoni, M., \& Bonga, W. G. (2018). The role of accounting information in the success of small \& medium enterprises (SMEs) in Zimbabwe: A case of Harare. Journal of Business and Management (DRJ-JBM), l(1), 01-15. https://papers.ssrn.com/sol3/papers.cfm?abstract_id=3114042. Accessed 12 May 2020.

31. Ogundana, O., Okere, W., Ayomoto, O., Adesanmi, D., Ibidunni, S., \& Ogunleye, O. (2017). ICT and accounting system of SMEs in Nigeria. Management Science Letters, 7(1), 1-8, DOI:10.5267/j.msl.2016.11.007.

32. Pavtar, A. A. (2017). Accounting Practices of SMEs: Challenges and Effects: A Survey of SMEs in Makurdi Metropolis-Benue State-Nigeria. World Journal of Finance and Investment Research, 2(1), 1629. http://iiard.com/index.php/WJFIR/article/view/1847. Accessed 12 May 2020.

33. Putra, Y. M. (2019). Analysis of Factors Affecting the Interests of SMEs Using Accounting Applications. Journal of Economics and Business, 2(3), DOI: 10.31014/aior.1992.02.03.129.

34. Rahman, M. M., Ahammed, M., Uddin, M., Rouf, M., \& Uddin, M. M. (2015). Obstacles and implementation of accounting software system in Small Medium Enterprises (SMEs): Case of South Asian perspective. Abdur and Uddin, Mohammad Main, Obstacles and Implementation of Accounting Software System in Small Medium Enterprises (SMEs): Case of South Asian Perspective (May 23, 2015), DOI:10.2139/ssrn.2609658.

35. Rkein, H., Issa, Z. A., Awada, F. J., \& Hejase, H. J. (2019). Impact of Automation on Accounting Profession and Employability: A Qualitative Assessment from Lebanon. Saudi Journal of Business Management, 4, 372-385, DOI:10.21276/sjbms.2019.4.4.10.

36. Rosli, K., Yeow, P. H., \& Siew, E. G. (2012). Factors influencing audit technology acceptance by audit firms: A new I-TOE adoption framework. Journal of Accounting and Auditing, 2012, 1, DOI: $10.5171 / 2012.876814$.

37. Sallem, N. R. M., Nasir, N. E. M., Nori, W. M. N. W. M., \& Kassim, C. K. H. C. K. (2017). Small and medium enterprises: Critical problems and possible solutions. International Business Management, 11(1), 47-52, DOI: $10.36478 / \mathrm{ibm} .2017 .47 .52$. 
38. Seethamraju, R. (2015). Adoption of software as a service (SaaS) enterprise resource planning (ERP) systems in small and medium sized enterprises (SMEs). Information systems frontiers, 17(3), 475-492, DOI: $10.1007 / \mathrm{s} 10796-014-9506-5$.

39. Shiraj, M. M. (2015). The impact of using computerized accounting systems (CAS) in financial reporting among SMEs:(Special Reference to the South Eastern Region, Sri Lanka). In 5th International Symposium-2015 South Eastern University of Sri Lanka. http://www.seu.ac.lk/researchandpublications/symposium/5th/abstract/businessandmanagement/16.pdf. Accessed 12 May 2020.

40. Sithole, S. (2015). The Relevance of International Financial Reporting Standards for Small and MediumSized Entities (IFRS for SMEs) in Swaziland. Journal of Modern Accounting and Auditing, 11(8), 383402, DOI:10.17265/1548-6583/2015.08.001.

41. Serpeninova, Y. S., Makarenko, S., \& Litvinova, M. (2019). Computer-assisted audit techniques: main advantages and disadvantages, DOI: 10.21272/ 1817-9215.2019.3-8.

42. Taiwo, J. N. (2016). Effect Of Ict On Accounting Information System And Organisational Performance: The Application Of Information And Communication Technology On Accounting Information System. European Journal of Business and Social Sciences, 5(2), 1-15. http://eprints.covenantuniversity.edu.ng/6925/\#.XsKQgWgzbIV. Accessed 12 May 2020.

43. Teddlie, C. and Tashakkori, A. (Eds) (2009), Foundations of Mixed Methods Research: Integrating Quantitative and Qualitative Approaches in the Social and Behavioral Sciences Sage Publications, DOI: 10.1016/j.aenj.2009.07.004.

44. Teru, S. P., Idoko, I. F., \& Bello, L. (2019). The Impact of E-Accounting in Modern Businesses. International Journal of Accounting \& Finance Review, 4(2), 1-4, DOI: https://doi.org/10.46281/ijafr.v4i2.355.

45. Tijani, O. M., \& Mohammed, A. K. (2013). Computer-based accounting systems in small and medium enterprises: Empirical evidence from a randomized trial in Nigeria. Universal Journal of Management, 1(1), 13-21. http://ir.unilag.edu.ng:8080/handle/123456789/2866. Accessed 12 May 2020.

46. Thottoli, M. M., Thomas K.V. \& Ahmed, E. R., (2019a). Adoption of Audit Software by Audit Firms: A Qualitative Study,Journal of Information and Computational Science, Volume 9 Issue 9 - 768-776. http://www.joics.org/gallery/ics-1436.pdf. Accessed 12 May 2020.

47. Thottoli, M. M., Thomas, K. V., \& Ahmed, E. R. (2019b). Qualitative Analysis on Information Communication Technology and Auditing Practices of Accounting Professionals. Journal of Information and Computational Science, 9(9). http://www.joics.org/gallery/ics-1398-.pdf. Accessed 12 May 2020.

48. Thottoli, M. M., Thomas K.V. \& Ahmed, E. R., (2019c). Examining the impact of Informaiton Communication Technology on Auditing Professionals: A Quantitative Studyl, Journal of Advanced Research in Dynamical and Control Systems, Volume 11 Issue 12, 476-488. http://www.joics.org/gallery/ics-1398-.pdf. Accessed 12 May 2020.

49. Tilahun, M. (2019). A Review on Determinants of Accounting Information System Adoption. Science Journal of Business and Management, 7(1), 17, DOI: 10.11648/j.sjbm.20190701.13.

50. Turner, L., Weickgenannt, A. B., \& Copeland, M. K. (2020). Accounting information systems: controls and processes. John Wiley \& Sons. https://books.google.com.om/books?

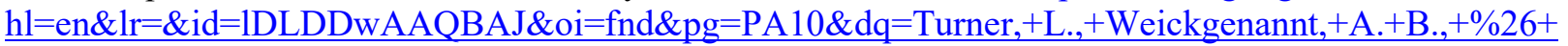
Copeland, + M. + K. $+(2020) .+$ Accounting + information + systems: + controls + and + processes. + John + Wiley + $\% 26+$ Sons.\&ots $=$ Jz1r6Sq-AF\&sig=1QmtHVTmi0vilg1CtAT0TMv26bk\&redir esc $=\mathrm{y} \# \mathrm{v}=$ onepag $\quad$ e\&q $\& \mathrm{f}=$ false. Accessed 12 May 2020.

51. Udegbunam, E. O., Uchenu, C. A., Odimmega, C. G., \& Nwogu, M. C. (2017). Electronic Accounting A Tool for Quality Management of Small and Medium Scale Enterprises (Smes) in the $21^{\text {st }}$ Century Nigeria. Nigerian Journal of Business Education (NIGJBED), 5(2), 86-95. http://www.nigjbed.com.ng/index.php/nigjbed/article/view/244. Accessed 12 May 2020.

52. Valerie, O., Abolade, F., \& Rowland, W. (2019). Accounting Software and Resolution to Financial Insolvency in Nigeria: A Meta-Analysis. Covenant Journal of Business and Social Sciences, 10(2).http://journals.covenantuniversity.edu.ng/index.php/cjbss/article/view/1801. Accessed 12 May 2020.

53. Yvonne, C., \& Nizam, I. (2018). The impact of accounting software on business performance. International Journal of Information System and Engineering, DOI: 10.24924/ijise/2018.04/v6.iss1/01.26. 
54. Zimmerman, J., \& Libby, D. V. (2017). Basic Bookkeeping and Accounting for the Private Practitioner. Handbook of Private Practice: Keys to Success for Mental Health Practitioners. https://books.google.com.om/books? $h \mathrm{l}=$ en $\& l \mathrm{l}=\mathrm{\&} i d=9 N Z K D g A A Q B A J \& o i=$ fnd\&pg $=P T 224 \& d q=$ Zimm erman $,+J .,+\% 26+L i b b y,+D .+V .+(2017) .+B A S I C+B O O K K E E P I N G+A N D+A C C O U N T I N G+F O R+T$ HE+PRIVATE +PRACTITIONER + Handbook + of + Private + Practice $:+$ Keys + to + Success + for + Mental + Health + Practitioners\&ots $=N T j m-y X d G \& \&$ sig $=G 2 Z N b t y c X g 5 M o O E Y b D l u B q 6 \quad J 6 Y \&$ redir esc $=y \# v=$ onepage\& $q \& f=$ false. Accessed 12 May 2020.

55. Zotorvie, J. S. T. (2017). A study of Financial Accounting Practices of Small and Medium Scale Enterprises (SMEs) in Ho Municipality, Ghana. International Journal of Academic Research in Business and Social Sciences, 7(7), 29-39, DOI: 10.6007/IJARBSS/v7-i7/3075.

56. International Financial Reporting Standards (IFRS). Official website of the IFRS. Retrieved from https://www.ifrs.org/issued-standards/list-of-standards/. Accessed April 17,2020.

57. Financial Accounting Standards Board (FASB). Official website of FASB. Retrieved from https://www.fasb.org/home. Accessed April 17, 2020.

58. Applicability of IFRS in Oman. Retrieved from https://www.ifrs.org/use-around-the-world/use-of-ifrsstandards-by-jurisdiction/oman/. Accessed on April 17,2020.

59. Promulgating the Commercial Company Law. Retrieved from https://www.cma.gov.om/Home/ CircularFileDownlad/5397. Accessed April 17,2020.

60. Capital Market Authority of Oman. Retrieved from https://www.cma.gov.om/. Accessed April 17,2020. 